\title{
Uranium Adsorption on Ion-Exchange Resins - Batch Testing
}

SV Mattigod

EC Golovich

DM Wellman
EA Cordova

RM Smith

December 2010

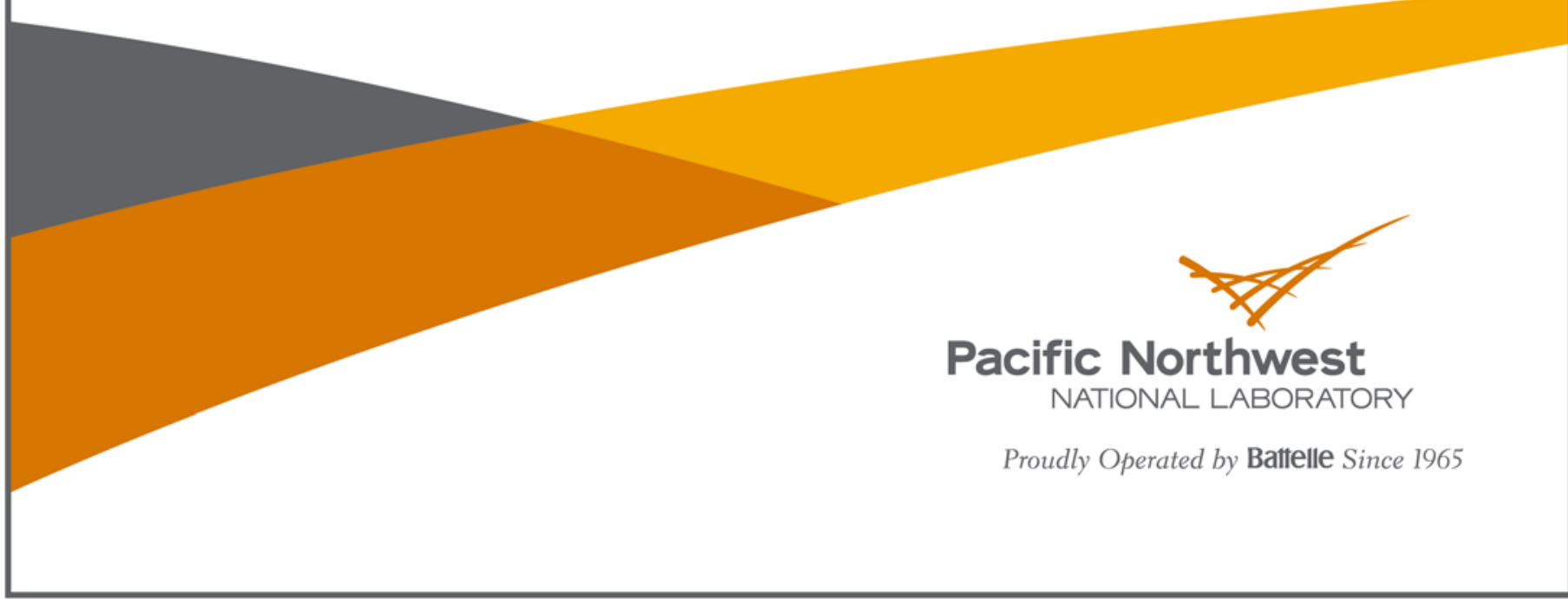




\title{
DISCLAIMER
}

This report was prepared as an account of work sponsored by an agency of the United States Government. Neither the United States Government nor any agency thereof, nor Battelle Memorial Institute, nor any of their employees, makes any warranty, express or implied, or assumes any legal liability or responsibility for the accuracy, completeness, or usefulness of any information, apparatus, product, or process disclosed, or represents that its use would not infringe privately owned rights. Reference herein to any specific commercial product, process, or service by trade name, trademark, manufacturer, or otherwise does not necessarily constitute or imply its endorsement, recommendation, or favoring by the United States Government or any agency thereof, or Battelle Memorial Institute. The views and opinions of authors expressed herein do not necessarily state or reflect those of the United States Government or any agency thereof.

\author{
PACIFIC NORTHWEST NATIONAL LABORATORY \\ operated by \\ BATTELLE \\ for the \\ UNITED STATES DEPARTMENT OF ENERGY \\ under Contract DE-AC05-76RL01830
}

Printed in the United States of America

Available to DOE and DOE contractors from the

Office of Scientific and Technical Information,

P.O. Box 62, Oak Ridge, TN 37831-0062;

ph: (865) 576-8401

fax: (865) 576-5728

email: reports@adonis.osti.gov

\footnotetext{
Available to the public from the National Technical Information Service, U.S. Department of Commerce, 5285 Port Royal Rd., Springfield, VA 22161 ph: (800) 553-6847 fax: (703) 605-6900

email: orders@ntis.fedworld.gov

online ordering: http://www.ntis.gov/ordering.htm
} 


\title{
Uranium Adsorption on Ion-Exchange Resins - Batch Testing
}

\author{
SV Mattigod \\ EA Cordova \\ EC Golovich \\ RM Smith \\ DM Wellman
}

December 2010

Prepared for

the U.S. Department of Energy

Under Contract DE-AC05-76RL01830

Pacific Northwest National Laboratory

Richland, Washington 99352 


\section{Summary}

The uranium adsorption performance of five resins (Dowex 1, Dowex 21K 16-30 [fresh], Dowex 21K 16-30 [regenerated], Purofine PFA600/4740, and ResinTech SIR-1200) were tested using unspiked, nitrate-spiked, and nitrate-spiked/pH adjusted source water from well 299-W19-36. These batch tests were conducted in support of a resin selection process in which the best resin to use for uranium treatment in the 200-West Area groundwater pump-and-treat system will be identified. The results from these tests are as follows:

- The data from the high-nitrate (1331 mg/L) tests indicated that Dowex 1, Dowex 21K 16-30 (fresh), Purofine PFA600/4740, and ResinTech SIR-1200 all adsorbed uranium similarly well with $\mathrm{K}_{\mathrm{d}}$ values ranging from $\sim 15,000$ to $95,000 \mathrm{ml} / \mathrm{g}$. All four resins would be considered suitable for use in the treatment system based on uranium adsorption characteristics.

- Lowering the $\mathrm{pH}$ of the high nitrate test conditions from 8.2 to 7.5 did not significantly change the uranium adsorption isotherms for the four tested resins. The $\mathrm{K}_{\mathrm{d}}$ values for these four resins under high nitrate (1338 mg/L), lower $\mathrm{pH}$ (7.5) ranged from 15,000 to 80,000 ml/g.

- Higher nitrate concentrations greatly reduced the uranium adsorption on all four resins. Tests conducted with unspiked (no amendments; nitrate at $337 \mathrm{mg} / \mathrm{L}$ and $\mathrm{pH}$ at 8.2) source water yielded $\mathrm{K}_{\mathrm{d}}$ values for Dowex 1, Dowex 21K 16-30 (fresh), Purofine PFA600/4740, and ResinTech SIR-1200 resins ranging from $\sim 800,000$ to $>3,000,000 \mathrm{ml} / \mathrm{g}$. These values are about two orders of magnitude higher than the $\mathrm{K}_{\mathrm{d}}$ values noted from tests conducted using amended source water.

- Compared to the fresh resin, the regenerated Dowex 21K 16-30 resin exhibited significantly lower uranium-adsorption performance under all test conditions. The calculated $K_{d}$ values for the regenerated resin were typically an order of magnitude lower than the values calculated for the fresh resin.

- Additional testing using laboratory columns is recommended to better resolve differences between the adsorption abilities of the resins and to develop estimates of uranium loading on the resins. By determining the quantity of uranium that each resin can adsorb and the time required to reach various levels of loading, resin lifetime in the treatment system can be estimated. 



\section{Acronyms and Abbreviations}

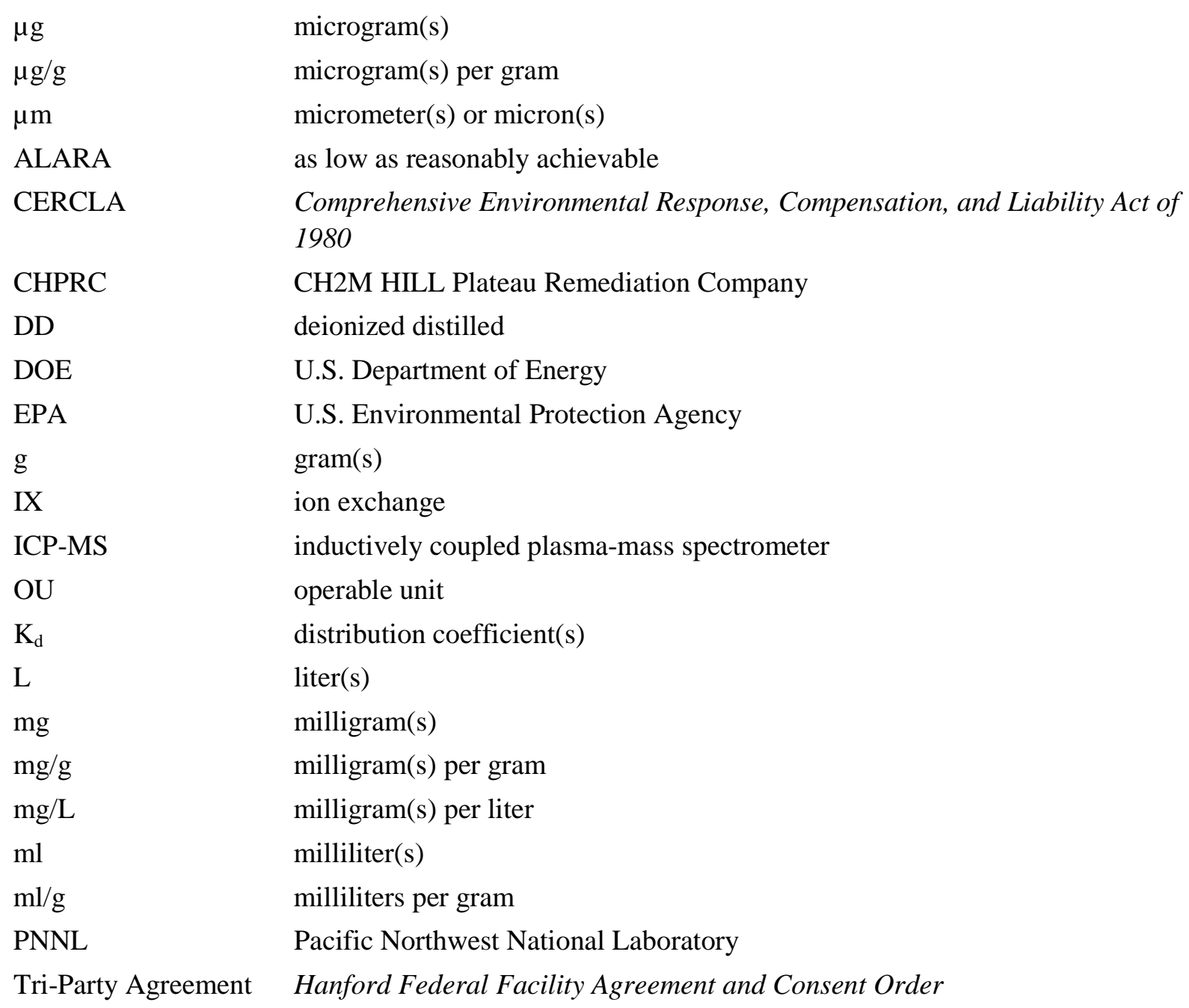





\section{Contents}

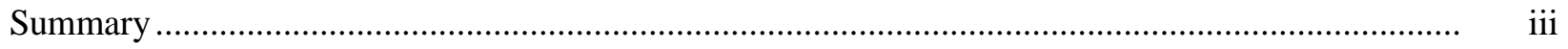

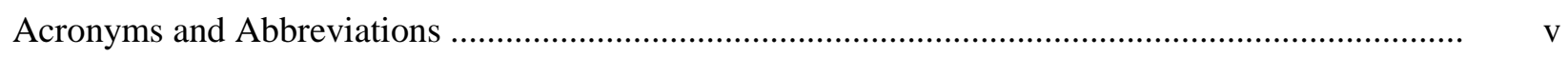

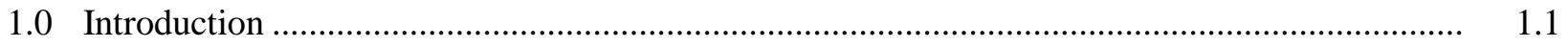

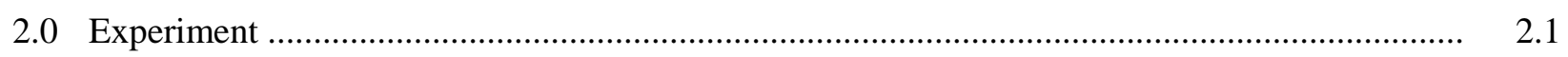

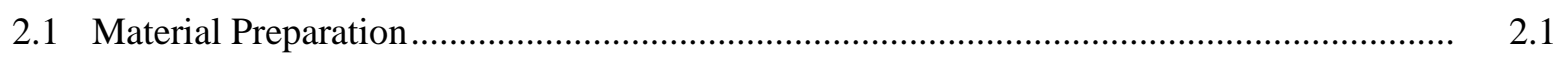

2.1.1 Ion Exchange Resin.......................................................................................... 2.1

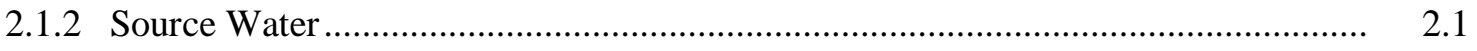

2.2 Batch Isotherm Tests..................................................................................... 2.1

2.2.1 High Nitrate Tests ............................................................................................ 2.2

2.2.2 High Nitrate-Low pH Tests .......................................................................... 2.2

2.2.3 Low-Nitrate Tests........................................................................................ 2.2

2.2.4 Duplicate Tests ............................................................................................. 2.2

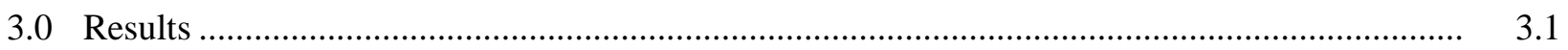

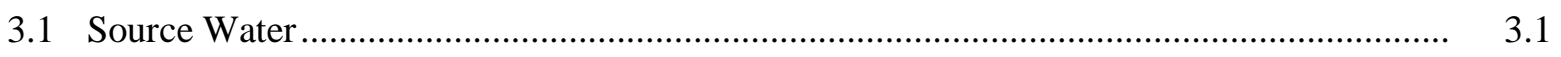

3.2 High-Nitrate Tests .................................................................................................... 3.1

3.3 High Nitrate-Low pH Tests................................................................................ 3.8

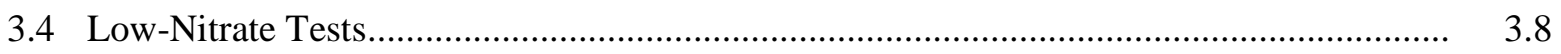

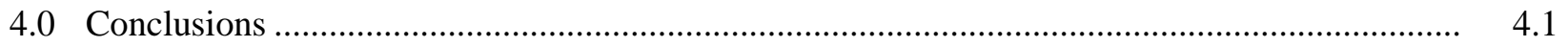

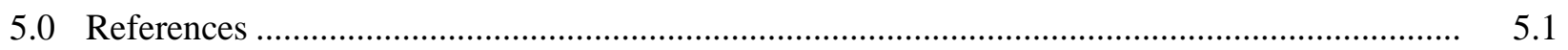

Appendix - Analytes and Analytical Methods ................................................................. A.1 


\section{Figures}

3.1 Langmuir Adsorption Isotherms for Uranium on Dowex 1 Resin........................................... 3.4

3.2 Langmuir Adsorption Isotherms for Uranium on Dowex 21K (Fresh) Resin ............................ 3.5

3.3 Langmuir Adsorption Isotherms for Uranium on Dowex 21K (Regenerated) Resin .................. 3.5

3.4 Langmuir Adsorption Isotherms for Uranium on Puroline PFA600-4740 Resin ....................... 3.6

3.5 Langmuir Adsorption Isotherms for Uranium on ResinTech SIR-1200 Resin.......................... 3.6

3.6 Uranium Adsorption Performance of Four of the Five IX-Resins Under Low Nitrate

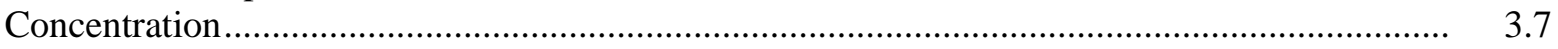

\section{Tables}

2.1 Test Matrix for Uranium Resin Batch Tests ........................................................................... 2.2

3.1 Concentrations of Specified Constituents in 299-W19-36 Source Water.................................... 3.1

3.2 Uranium-Adsorption Data for Dowex 1 Resin ....................................................................... 3.2

3.3 Uranium Adsorption Data for Dowex 21K 16-30 (Fresh) Resin............................................... 3.2

3.4 Uranium Adsorption Data for Dowex 21K 16-30 (Regenerated) Resin ...................................... 3.3

3.5 Uranium Adsorption Data for Purofine PFA600/4740 Resin ....................................................... 3.3

3.6 Uranium Adsorption Data for ResinTech SIR-1200 Resin. .................................................... 3.4

3.7 Langmuir Constants for Uranium Adsorption on Selected Ion-Exchange Resins........................ 3.7 


\subsection{Introduction}

CH2M HILL Plateau Remediation Company (CHPRC) is currently developing a 200-West Area groundwater pump-and-treat system to remove radioactive and non-radioactive hazardous constituents from groundwater beneath the area. Pump-and-treat is the remedial action selected under the Comprehensive Environmental Response, Compensation, and Liability Act of 1980 (CERCLA) Record of Decision for the 200-ZP-1 Operable Unit (OU) (Record of Decision Hanford 200 Area 200-ZP-1 Superfund Site, Benton County, Washington [EPA et al. 2008]). This action is being performed in accordance with the Hanford Federal Facility Agreement and Consent Order (Tri-Party Agreement) (Ecology et al. 1989). The treatment design is based, in part, on the removal of selected contaminants of concern using various sorbent media. CHPRC asked Pacific Northwest National Laboratory (PNNL) to perform treatability testing to quantify the ability of selected ion-exchange (IX) resins to adsorb uranium from groundwater in the Hanford Site's 200-West Area.

Laboratory sorption experiments included batch tests from which the sorption characteristics of each of the IX resins were quantified. Using IX resin samples and groundwater provided by CHPRC, PNNL researchers tested five IX resins using batch techniques. The batch isotherm tests were conducted according to the approved test plan (CHPRC 2010).

The goals of the batch testing were as follows:

- Confirm that the IX process will remove uranium from groundwater at well 299-W19-36 in the 200-UP-1 OU.

- Identify suitable IX resins for possible use in the new 200-West Area pump-and-treat system.

- Determine the uranium-loading capacity of these resins and the potential loading of other radionuclides and non-radionuclide constituents that may affect uranium removal or disposal of spent resin.

- Measure IX resin performance when the $\mathrm{pH}$ of the groundwater is lowered by 0.5 standard units.

- Determine the effect of increased nitrate concentration (approximately $1400 \mathrm{mg} / \mathrm{L}$ ) of uranium adsorption on IX resins.

Batch testing involved preparing the IX resins and groundwater (including adjusting $\mathrm{pH}$ and nitrate concentrations in the latter), performing contact tests, analyzing solutions, compiling data, and reporting results. The ensuing sections of this report describe the experiment, summarize the results of batch isotherm tests, and provide related conclusions. 


\subsection{Experiment}

\subsection{Material Preparation}

\subsubsection{Ion Exchange Resin}

The as-received ion exchange materials were prepared by first centrifuge washing two times with deionized distilled (DD) water to remove any soluble contaminants accumulated during storage. Next, the resins were soaked in DD water for 2 hours to ensure proper hydration. After hydration, the excess water was decanted, and the resins were stored wet until needed.

\subsubsection{Source Water}

The source water from well 299-W19-36 was analyzed for $\mathrm{pH}$, alkalinity, sulfate $\left(\mathrm{SO}_{4}\right)$, nitrate $\left(\mathrm{NO}_{3}\right)$, uranium, and technetium-99. The $\mathrm{pH}$ of a portion of well 299-W19-36 source water was lowered by 0.5 standard units using $0.1 \mathrm{~N} \mathrm{HCl}$ for use in batch tests to examine the effect of lowered $\mathrm{pH}$ on uranium adsorption. The nitrate concentration of another portion of source water was enhanced to $\sim 1400 \mathrm{mg} / \mathrm{L}$ to test the effect of higher nitrate concentrations on adsorption of uranium. Unspiked source water (natural nitrate concentration) was used for another set of batch isotherm tests.

\subsection{Batch Isotherm Tests}

Batch isotherm tests were conducted using the standard practice for determining adsorption isotherms for IX resins (as suggested in Application Information - DOWEX Ion Exchange Resins; Equilibrium Isotherm Testing for Liquid Phase Applications (DOW 1997) as a guide with modifications to comply with the U.S. Department of Energy (DOE) principle of limiting radiation dose to as low as reasonably achievable (ALARA). Therefore, the mass of resin and solution volume used in each batch contact was reduced to minimize waste volume. The following resin-to-solution ratios were used in most of the batch isotherm tests:

- Ratio \#1 - 0.25 g resin/50 ml solution

- Ratio \#2 - 0.50 g resin/50 ml solution

- Ratio \#3 - 0.75 g resin/50 ml solution

- Ratio \#4 - 1.00 g resin/50 ml solution.

The test matrix is shown below in Table 2.1.

All batch adsorption tests were conducted for 18 hours. During that time, the centrifuge tubes were agitated continuously so the IX resin and groundwater remain well mixed. This was done in a SHEL Lab shaking incubator at $250 \mathrm{RPM}$ and $18^{\circ} \mathrm{C}$. After the required contact time of 18 hours, the tubes were centrifuged in a Thermo Centra GP8R centrifuge for 15 minutes at 2500 RPM. A $0.45-\mu$ m syringe filter was then used to separate the groundwater from the IX resin, and a 10-ml aliquot was taken for uranium analysis. See Appendix for description of analysis procedure. The batch-testing procedure was repeated for each IX resin sample, as described in Table 2.1. 
Table 2.1. Test Matrix for Uranium Resin Batch Tests

\begin{tabular}{|c|c|c|c|c|c|}
\hline \multirow[b]{2}{*}{ Isotherm } & \multirow[b]{2}{*}{ Ion Exchange Resin } & \multicolumn{4}{|c|}{ Resin/Solution Ratio } \\
\hline & & Test \#1 & Test \#2 & Test \#3 & Test \#4 \\
\hline 1 & Dowex 1 & Ratio \#1 & Ratio \#2 & Ratio \#3 & Ratio \#4 \\
\hline 2 & Dowex 21 K (fresh) & Ratio \#1 & Ratio \#2 & Ratio \#3 & Ratio \#4 \\
\hline 3 & Dowex 21 K (regenerated from 100 Area tests) & Ratio \#1 & Ratio \#2 & Ratio \#3 & Ratio \#4 \\
\hline 4 & Purofine PFA600/4740 & Ratio \#1 & Ratio \#2 & Ratio \#3 & Ratio \#4 \\
\hline 5 & ResinTech SIR-1200 & Ratio \#1 & Ratio \#2 & Ratio \#3 & Ratio \#4 \\
\hline \multicolumn{6}{|c|}{$\begin{array}{l}\text { Dowex }{ }^{\circledR} \text { is a registered trademark of The Dow Chemical Company, Midland, Michigan. } \\
\text { Purofine }{ }^{\circledR} \text { and Purolite }{ }^{\circledR} \text { are the registered trademarks of The Purolite Company, Bala Cynwyd, Pennsylvania. } \\
\text { ResinTech } \AA \text { is a registered trademark of ResinTech, Inc, West Berlin, New Jersey. }\end{array}$} \\
\hline
\end{tabular}

\subsubsection{High Nitrate Tests}

The high nitrate batch isotherm tests were conducted by measuring appropriate quantities of IX resin products into a set of labeled centrifuge tubes. The required volume (50 ml) of nitrate-spiked ( $\sim 1400 \mathrm{mg} / \mathrm{L}$ ) source water from well 299-W19-36 was added to achieve the appropriate resin and solution ratios as specified in Table 2.1. The adsorption tests were conducted as specified in Section 2.2.

\subsubsection{High Nitrate-Low pH Tests}

The high nitrate-low $\mathrm{pH}$ batch isotherm tests were conducted by measuring appropriate quantities of IX resin products into a set of labeled centrifuge tubes. The required volume of nitrate-spiked ( $1400 \mathrm{mg} / \mathrm{L}$ ), pH-adjusted (lowered by $0.5 \mathrm{pH}$ units) source water from well 299-W19-36 was added to achieve the appropriate resin and solution ratios as specified in Table 2.1. The adsorption tests were conducted as specified in Section 2.2.

\subsubsection{Low-Nitrate Tests}

The low-nitrate (as received) batch isotherm tests were conducted by measuring appropriate quantities of IX resin products into a set of labeled centrifuge tubes. The required volume of source water (without any nitrate spiking and $\mathrm{pH}$ adjustment) from well 299-W19-36 was added to achieve the appropriate resin and solution ratios as specified in Table 2.1. The adsorption tests were conducted as specified in Section 2.2.

\subsubsection{Duplicate Tests}

After the initial test sets were complete, CHPRC reviewed the data and selected isotherms for duplicate runs.

\subsubsection{ResinTech SIR-1200 - Low Nitrate}

The duplicate batch isotherm tests for ResinTech SIR-1200 were conducted by measuring appropriate quantities of IX resin products into a set of labeled centrifuge tubes. The required volume of source water 
(without any nitrate spiking and $\mathrm{pH}$ adjustment) from well 299-W19-36 was added to achieve the appropriate resin and solution ratios as specified in Table 2.1. The adsorption tests were conducted in accordance with Section 2.2.

\subsubsection{Dowex 21K Regenerated - High Nitrate}

The duplicate batch isotherm tests for Dowex 21K (regenerated from 100 Area tests) were conducted by measuring appropriate quantities of IX resin products into a set of labeled centrifuge tubes. The required volume of nitrate-spiked ( $1400 \mathrm{mg} / \mathrm{L})$ source water from well 299-W19-36 was added to achieve the following resin and solution combinations:

- Ratio \#1 - 0.01 g resin/50 ml solution

- Ratio \#2 - 0.50 g resin/50 ml solution

- Ratio \#3 - 1.00 g resin/50 ml solution

- Ratio \#4 - 2.00 g resin/50 ml solution.

The adsorption tests were conducted in accordance with Section 2.2. 


\subsection{Results}

\subsection{Source Water}

The results of the initial analyses of source water from 299-W19-36 used in the batch isotherm experiments are listed in Table 3.1.

Table 3.1. Concentrations of Specified Constituents in 299-W19-36 Source Water

\begin{tabular}{llccc}
\hline \multicolumn{1}{c}{ Constituent } & Units & $\begin{array}{c}\text { Low Nitrate, } \\
\text { As Received }^{(\mathrm{a})}\end{array}$ & High Nitrate & $\begin{array}{c}\text { High Nitrate, } \\
\text { Low } \mathrm{pH}\end{array}$ \\
\hline $\mathrm{pH}$ & $\mathrm{SU}$ & 8.20 & 8.19 & 7.50 \\
$\begin{array}{l}\text { Alkalinity } \\
(\text { as CaCO }\end{array}$ ) & $\mathrm{mg} / \mathrm{L}$ & 116 & 112 & 100 \\
Sulfate & $\mathrm{mg} / \mathrm{L}$ & 50 & 49 & 45 \\
Nitrate & $\mathrm{mg} / \mathrm{L}$ & 317 & 1331 & 1338 \\
Uranium & $\mu \mathrm{g} / \mathrm{L}$ & 171.61 & 179.99 & 170.95 \\
Technetium-99 & $\mu \mathrm{g} / \mathrm{L}$ & 0.385 & 0.383 & 0.384 \\
\hline
\end{tabular}

(a) Average of duplicate measurements.

Spiking with nitrate and $\mathrm{pH}$ adjustments did not significantly change the technetium-99 concentrations.

\subsection{High-Nitrate Tests}

The results of the batch isotherm tests for all five ion-exchange resins are listed in Tables 3.2-3.6 and displayed graphically in Figures 3.1-3.6. The parameters derived from Langmuir isotherm fit to these data are listed in Table 3.7.

Data from the high-nitrate $(1331 \mathrm{mg} / \mathrm{L})$ tests indicated that the uranium adsorption performance of Dowex 1, Dowex 21K 16-30 (fresh), Purofine PFA600/4740, and ResinTech SIR-1200 were similar (Tables 3.2, 3.3, 3.5 and 3.6). At the lowest resin-to-solution ratio, the uranium adsorption for these four resins typically ranged from 32.00 to $33.75 \mu \mathrm{g} / \mathrm{g}$, and at the highest resin-to-solution ratio, it ranged from 8.24 to $8.49 \mu \mathrm{g} / \mathrm{g}$, respectively. The calculated distribution coefficients $\left(\mathrm{K}_{\mathrm{d}}\right)$ for these four resin ranged from $\sim 15,000$ to $94,000 \mathrm{ml} / \mathrm{g}$. The adsorption isotherms for these exchange resins fit the Langmuir equation with predicted maxima of 84.87, 57.3, 44.41 and $44.57 \mu \mathrm{g} / \mathrm{g}$ for Dowex 1, Dowex 21K 16-30 (fresh), Purofine PFA600/4740, and ResinTech SIR-1200, respectively (Table 3.7).

Compared to the Dowex 21K 16-30 (fresh resin), the regenerated form of this resin exhibited diminished uranium-adsorption performance. Depending on the resin-to-solution ratio, the final uranium concentrations in contact with the regenerated resin were 5 to 30 times higher than the concentrations measured in solutions in contact with the fresh resin (Tables 3.3 and 3.4) because of differences in adsorption capability. The adsorption isotherm for the regenerated resin was linear within the tested 
range of resin-to-solution ratios (Figure 3.3) and the $\mathrm{K}_{\mathrm{d}}$ ranged from 2,000 to 4,000 ml/g (Table 3.4), reflecting its attenuated performance characteristics compared to the fresh resin.

Table 3.2. Uranium-Adsorption Data for Dowex 1 Resin

\begin{tabular}{|c|c|c|c|c|c|c|}
\hline Sample \# & $\begin{array}{l}\text { U Initial Conc. } \\
(\mu \mathrm{g} / \mathrm{L})\end{array}$ & $\begin{array}{l}\text { U Final Conc. } \\
(\mu \mathrm{g} / \mathrm{L})\end{array}$ & $\begin{array}{c}\text { Resin Mass } \\
\text { (g) }\end{array}$ & $\begin{array}{c}\text { Soln. Vol. } \\
\text { (ml) }\end{array}$ & $\begin{array}{l}\text { U Ads. } \\
(\mu g / g)\end{array}$ & $\begin{array}{c}\mathrm{K}_{\mathrm{d}} \\
(\mathrm{ml} / \mathrm{g})\end{array}$ \\
\hline \multicolumn{7}{|c|}{ Nitrate: $1331 \mathrm{mg} / \mathrm{L}$} \\
\hline DOW1-S1-R1-1 & 179.99 & 2.0693 & 0.273 & 49.10 & 32.00 & 15,460 \\
\hline DOW1-S1-R2-1 & 179.99 & 0.6968 & 0.492 & 49.10 & 17.89 & 25,680 \\
\hline DOW1-S1-R3-1 & 179.99 & 0.2567 & 0.777 & 49.06 & 11.35 & 44,200 \\
\hline DOW1-S1-R4-1 & 179.99 & 0.1346 & 1.072 & 49.14 & 8.24 & 61,240 \\
\hline \multicolumn{7}{|c|}{ Nitrate: 1338 mg/L, pH: 7.5} \\
\hline DOW1-S2-R1-1 & 170.95 & 2.1458 & 0.259 & 49.06 & 31.98 & 14,900 \\
\hline DOW1-S2-R2-1 & 170.95 & 0.5447 & 0.555 & 49.18 & 15.10 & 27,720 \\
\hline DOW1-S2-R3-1 & 170.95 & 0.2771 & 0.756 & 49.08 & 11.08 & 39,980 \\
\hline DOW1-S2-R4-1 & 170.95 & 0.1532 & 1.008 & 49.17 & 8.33 & 54,380 \\
\hline \multicolumn{7}{|c|}{ Nitrate: 317 mg/L } \\
\hline DOW1-S3-R1-1 & 171.61 & 0.0270 & 0.261 & 49.26 & 32.38 & $1,200,000$ \\
\hline DOW1-S3-R2-1 & 171.61 & 0.0114 & 0.512 & 49.80 & 16.69 & $1,464,000$ \\
\hline DOW1-S3-R3-1 & 171.61 & $<0.0110$ & 0.772 & 49.85 & $>11.08$ & $>1,007,000$ \\
\hline DOW1-S3-R4-1 & 171.61 & $<0.0110$ & 1.016 & 49.53 & $>8.36$ & $>760,000$ \\
\hline
\end{tabular}

Table 3.3. Uranium Adsorption Data for Dowex 21K 16-30 (Fresh) Resin

\begin{tabular}{|c|c|c|c|c|c|c|}
\hline Sample \# & $\begin{array}{l}\text { U Initial Conc. } \\
\qquad(\mu \mathrm{g} / \mathrm{L})\end{array}$ & $\begin{array}{l}\text { U Final Conc. } \\
\quad(\mu \mathrm{g} / \mathrm{L})\end{array}$ & $\begin{array}{c}\text { Resin Mass } \\
\text { (g) }\end{array}$ & $\begin{array}{l}\text { Soln. Vol. } \\
\text { (ml) }\end{array}$ & $\begin{array}{l}\text { U Ads } \\
(\mu \mathrm{g} / \mathrm{g})\end{array}$ & $\begin{array}{c}\mathrm{K}_{\mathrm{d}} \\
(\mathrm{ml} / \mathrm{g})\end{array}$ \\
\hline \multicolumn{7}{|c|}{ Nitrate: $1331 \mathrm{mg} / \mathrm{L}$} \\
\hline DOWF-S1-R1-1 & 179.99 & 1.6257 & 0.266 & 49.06 & 32.90 & 20,240 \\
\hline DOWF-S1-R2-1 & 179.99 & 0.5862 & 0.518 & 49.14 & 17.02 & 29,030 \\
\hline DOWF-S1-R3-1 & 179.99 & 0.2983 & 0.777 & 49.13 & 11.36 & 38,080 \\
\hline DOWF-S1-R4-1 & 179.99 & 0.1652 & 1.063 & 49.69 & 8.41 & 50,870 \\
\hline \multicolumn{7}{|c|}{ Nitrate: 1338 mg/L, pH: 7.5} \\
\hline DOWF-S2-R1-1 & 170.95 & 1.7537 & 0.265 & 49.09 & 31.34 & 17,870 \\
\hline DOWF-S2-R2-1 & 170.95 & 0.5992 & 0.511 & 49.05 & 16.35 & 27,290 \\
\hline DOWF-S2-R3-1 & 170.95 & 0.2588 & 0.778 & 49.09 & 10.77 & 41,620 \\
\hline DOWF-S2-R4-1 & 170.95 & 0.1613 & 1.003 & 49.36 & 8.40 & 52,110 \\
\hline \multicolumn{7}{|c|}{ Nitrate: 317 mg/L } \\
\hline DOWF-S3-R1-1 & 171.61 & 0.0405 & 0.262 & 49.43 & 32.37 & 799,000 \\
\hline DOWF-S3-R2-1 & 171.61 & $<0.1100$ & 0.509 & 49.29 & $>16.62$ & $>1,511,000$ \\
\hline DOWF-S3-R3-1 & 171.61 & $<0.0110$ & 0.766 & 49.69 & $>11.13$ & $>1,012,000$ \\
\hline DOWF-S3-R4-1 & 171.61 & $<0.0110$ & 1.037 & 49.22 & $>8.14$ & $>740,000$ \\
\hline
\end{tabular}


Table 3.4. Uranium Adsorption Data for Dowex 21K 16-30 (Regenerated) Resin

\begin{tabular}{|c|c|c|c|c|c|c|}
\hline Sample \# & $\begin{array}{l}\text { U Initial Conc. } \\
\qquad(\mu \mathrm{g} / \mathrm{L})\end{array}$ & $\begin{array}{c}\text { U Final } \\
\text { Conc. }(\mu \mathrm{g} / \mathrm{L})\end{array}$ & $\begin{array}{l}\text { Resin Mass } \\
\text { (g) }\end{array}$ & $\begin{array}{l}\text { Soln. Vol. } \\
\text { (ml) }\end{array}$ & $\begin{array}{l}\text { U Ads } \\
(\mu g / g)\end{array}$ & $\begin{array}{c}\mathrm{K}_{\mathrm{d}} \\
(\mathrm{ml} / \mathrm{g})\end{array}$ \\
\hline \multicolumn{7}{|c|}{ Nitrate: 1331 mg/L } \\
\hline DOWR-S1-R1-1 & 179.99 & 8.1055 & 0.275 & 49.12 & 30.70 & 3,800 \\
\hline DOWR-S1-R2-1 & 179.99 & 6.7722 & 0.527 & 49.11 & 16.14 & 2,400 \\
\hline DOWR-S1-R3-1 & 179.99 & 5.5457 & 0.775 & 49.36 & 11.11 & 2,000 \\
\hline DOWR-S1-R4-1 & 179.99 & 4.8251 & 1.067 & 49.11 & 8.06 & 1,700 \\
\hline \multicolumn{7}{|c|}{ Nitrate: 1338 mg/L, pH: 7.5} \\
\hline DOWR-S2-R1-1 & 170.95 & 7.9473 & 0.268 & 49.02 & 29.81 & 3,750 \\
\hline DOWR-S2-R2-1 & 170.95 & 5.7684 & 0.516 & 49.14 & 15.73 & 2,700 \\
\hline DOWR-S2-R3-1 & 170.95 & 5.3539 & 0.759 & 49.14 & 10.72 & 2,000 \\
\hline DOWR-S2-R4-1 & 170.95 & 4.5287 & 1.025 & 49.56 & 8.05 & 1,800 \\
\hline \multicolumn{7}{|c|}{ Nitrate: 317 mg/L } \\
\hline DOWR-S3-R1-1 & 171.61 & 0.9002 & 0.274 & 49.22 & 30.67 & 34,060 \\
\hline DOWR-S3-R2-1 & 171.61 & 0.6850 & 0.526 & 49.38 & 16.05 & 23,420 \\
\hline DOWR-S3-R3-1 & 171.61 & 0.6355 & 0.772 & 49.08 & 10.87 & 17,110 \\
\hline DOWR-S3-R4-1 & 171.61 & 0.5557 & 1.017 & 49.42 & 8.31 & 14,960 \\
\hline \multicolumn{7}{|c|}{ Nitrate: 1331 mg/L - Duplicate } \\
\hline DOWR-S4-R1-1 & 182.88 & 76.265 & 0.014 & 45.881 & 349.40 & 4,580 \\
\hline DOWR-S4-R2-1 & 182.88 & 7.170 & 0.432 & 45.524 & 18.52 & 2,580 \\
\hline DOWR-S4-R3-1 & 182.88 & 5.140 & 0.902 & 45.241 & 8.91 & 1,730 \\
\hline DOWR-S4-R4-1 & 182.88 & 4.155 & 1.814 & 45.971 & 4.53 & 1,090 \\
\hline
\end{tabular}

Table 3.5. Uranium Adsorption Data for Purofine PFA600/4740 Resin

\begin{tabular}{|c|c|c|c|c|c|c|}
\hline Sample \# & $\begin{array}{c}\text { U Initial Conc. } \\
(\mu \mathrm{g} / \mathrm{L})\end{array}$ & $\begin{array}{l}\text { U Final Conc. } \\
(\mu \mathrm{g} / \mathrm{L})\end{array}$ & $\begin{array}{c}\text { Resin Mass } \\
\text { (g) }\end{array}$ & $\begin{array}{c}\text { Soln. Vol. } \\
(\mathrm{ml})\end{array}$ & $\begin{array}{l}\text { U Ads. } \\
(\mu g / g)\end{array}$ & $\begin{array}{c}\mathrm{K}_{\mathrm{d}} \\
(\mathrm{ml} / \mathrm{g})\end{array}$ \\
\hline \multicolumn{7}{|c|}{ Nitrate: $1331 \mathrm{mg} / \mathrm{L}$} \\
\hline PPFA-S1-R1-1 & 179.99 & 1.7678 & 0.259 & 49.05 & 33.75 & 19,090 \\
\hline PPFA-S1-R2-1 & 179.99 & 0.4384 & 0.521 & 49.07 & 16.91 & 38,570 \\
\hline PPFA-S1-R3-1 & 179.99 & 0.1868 & 0.797 & 49.58 & 11.19 & 59,890 \\
\hline PPFA-S1-R4-1 & 179.99 & 0.0881 & 1.069 & 49.07 & 8.26 & 93,770 \\
\hline \multicolumn{7}{|c|}{ Nitrate: 1338 mg/L, pH: 7.5} \\
\hline PPFA-S2-R1-1 & 170.95 & 1.8153 & 0.259 & 49.04 & 32.02 & 17,640 \\
\hline PPFA-S2-R2-1 & 170.95 & 0.8396 & 0.557 & 49.34 & 15.07 & 17,950 \\
\hline PPFA-S2-R3-1 & 170.95 & 0.1937 & 0.750 & 49.59 & 11.29 & 58,290 \\
\hline PPFA-S2-R4-1 & 170.95 & 0.0992 & 1.021 & 49.12 & 8.22 & 82,850 \\
\hline \multicolumn{7}{|c|}{ Nitrate: 317 mg/L } \\
\hline PPFA-S3-R1-1 & 171.61 & 0.0139 & 0.270 & 49.48 & 31.44 & $2,259,000$ \\
\hline PPFA-S3-R2-1 & 171.61 & $<0.0110$ & 0.552 & 49.36 & $>15.34$ & $>1,395,000$ \\
\hline PPFA-S3-R3-1 & 171.61 & $<0.0110$ & 0.762 & 49.77 & $>11.21$ & $>1,019,000$ \\
\hline PPFA-S3-R4-1 & 171.61 & $<0.0110$ & 1.021 & 49.15 & $>8.26$ & $>751,000$ \\
\hline
\end{tabular}


Table 3.6. Uranium Adsorption Data for ResinTech SIR-1200 Resin.

\begin{tabular}{|c|c|c|c|c|c|c|}
\hline Sample \# & $\begin{array}{l}\text { U Initial Conc. } \\
\qquad(\mu \mathrm{g} / \mathrm{L})\end{array}$ & $\begin{array}{l}\text { U Final Conc. } \\
(\mu \mathrm{g} / \mathrm{L})\end{array}$ & $\begin{array}{c}\text { Resin Mass } \\
\text { (g) }\end{array}$ & $\begin{array}{l}\text { Soln. Vol. } \\
(\mathrm{ml})\end{array}$ & $\begin{array}{l}\text { U Ads. } \\
(\mu g / g)\end{array}$ & $\begin{array}{c}\mathrm{K}_{\mathrm{d}} \\
(\mathrm{ml} / \mathrm{g})\end{array}$ \\
\hline \multicolumn{7}{|c|}{ Nitrate: 1331 mg/L } \\
\hline RTSI-S1-R1-1 & 179.99 & 1.8394 & 0.260 & 49.08 & 33.63 & 18,280 \\
\hline RTSI-S1-R2-1 & 179.99 & 0.4380 & 0.543 & 49.14 & 16.25 & 37,100 \\
\hline RTSI-S1-R3-1 & 179.99 & 0.2029 & 0.757 & 49.05 & 11.65 & 57,420 \\
\hline RTSI-S1-R4-1 & 179.99 & 0.1066 & 1.047 & 49.39 & 8.49 & 79,630 \\
\hline \multicolumn{7}{|c|}{ Nitrate: 1338 mg/L, pH: 7.5} \\
\hline RTSI-S2-R1-1 & 170.95 & 1.5566 & 0.256 & 49.10 & 32.49 & 20,870 \\
\hline RTSI-S2-R2-1 & 170.95 & 0.3873 & 0.551 & 49.17 & 15.22 & 39,300 \\
\hline RTSI-S2-R3-1 & 170.95 & 0.2117 & 0.743 & 49.21 & 11.31 & 53,420 \\
\hline RTSI-S2-R4-1 & 170.95 & 0.1137 & 0.995 & 49.10 & 8.43 & 74,130 \\
\hline \multicolumn{7}{|c|}{ Nitrate: $317 \mathrm{mg} / \mathrm{L}$} \\
\hline RTSI-S3-R1-1 & 171.61 & $<0.0110$ & 0.297 & 49.52 & $>28.61$ & $>2,601,000$ \\
\hline RTSI-S3-R2-1 & 171.61 & $<0.0110$ & 0.553 & 49.72 & $>15.43$ & $>1,406,000$ \\
\hline RTSI-S3-R3-1 & 171.61 & $<0.0110$ & 0.762 & 49.65 & $>11.18$ & $>1,016,000$ \\
\hline RTSI-S3-R4-1 & 171.61 & $<0.0110$ & 1.045 & 49.28 & $>8.09$ & $>736,000$ \\
\hline \multicolumn{7}{|c|}{ Nitrate 317 mg/L - Duplicate } \\
\hline RTSI-S4-R1-1 & 182.32 & $<0.0110$ & 0.231 & 46.764 & $>36.91$ & $>3,482,000$ \\
\hline RTSI-S4-R2-1 & 182.32 & $<0.0110$ & 0.473 & 45.852 & $>17.67$ & $>1,667,000$ \\
\hline RTSI-S4-R3-1 & 182.32 & $<0.0110$ & 0.676 & 46.171 & $>12.45$ & $>1,175,000$ \\
\hline RTSI-S4-R4-1 & 182.32 & $<0.0110$ & 0.913 & 46.214 & $>9.23$ & $>871,000$ \\
\hline
\end{tabular}

\section{Dowex 1}

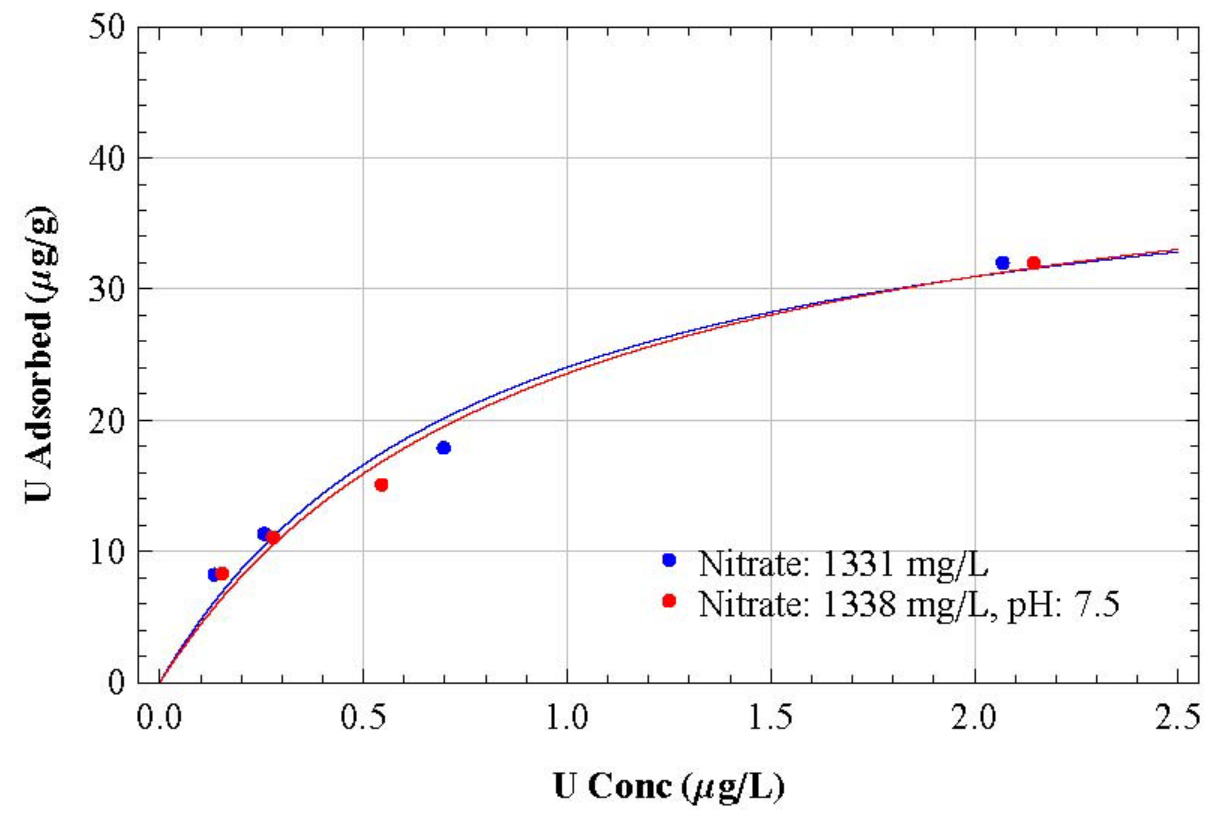

Figure 3.1. Langmuir Adsorption Isotherms for Uranium on Dowex 1 Resin 


\section{Dowex 21K Fresh}

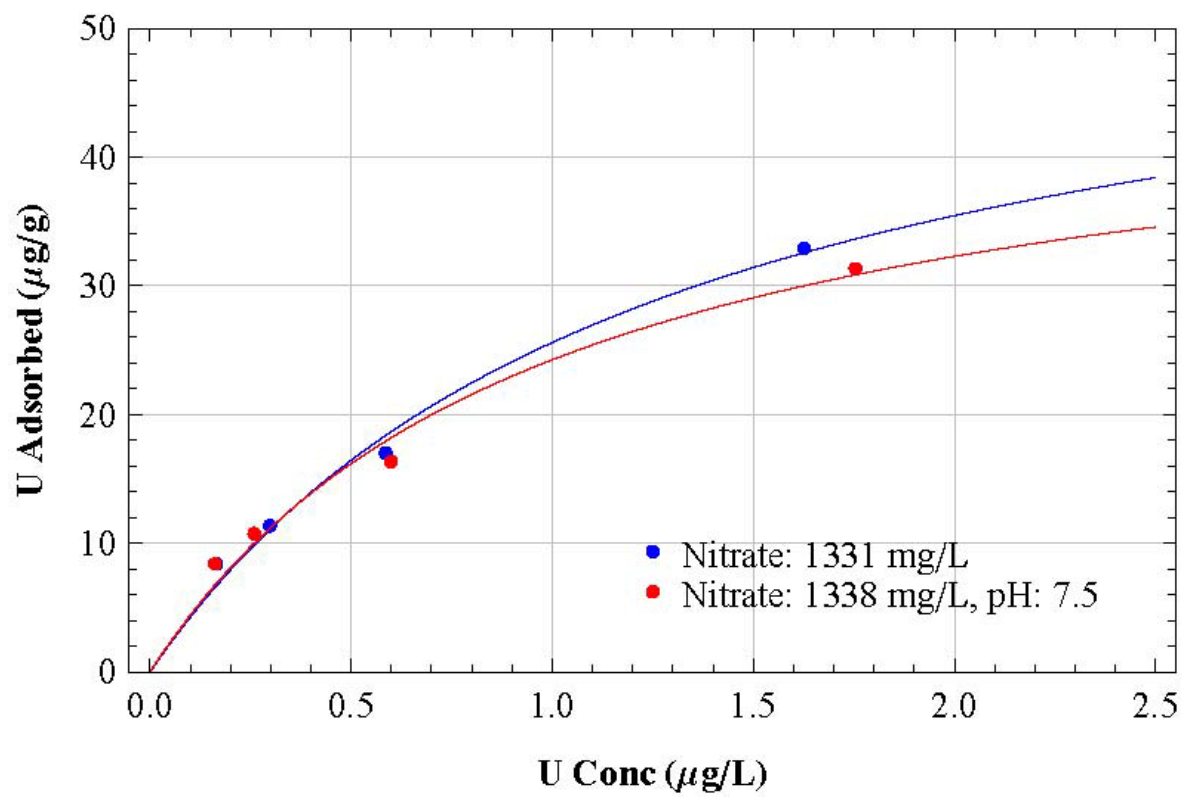

Figure 3.2. Langmuir Adsorption Isotherms for Uranium on Dowex 21K (Fresh) Resin

\section{Dowex 21K Regen}

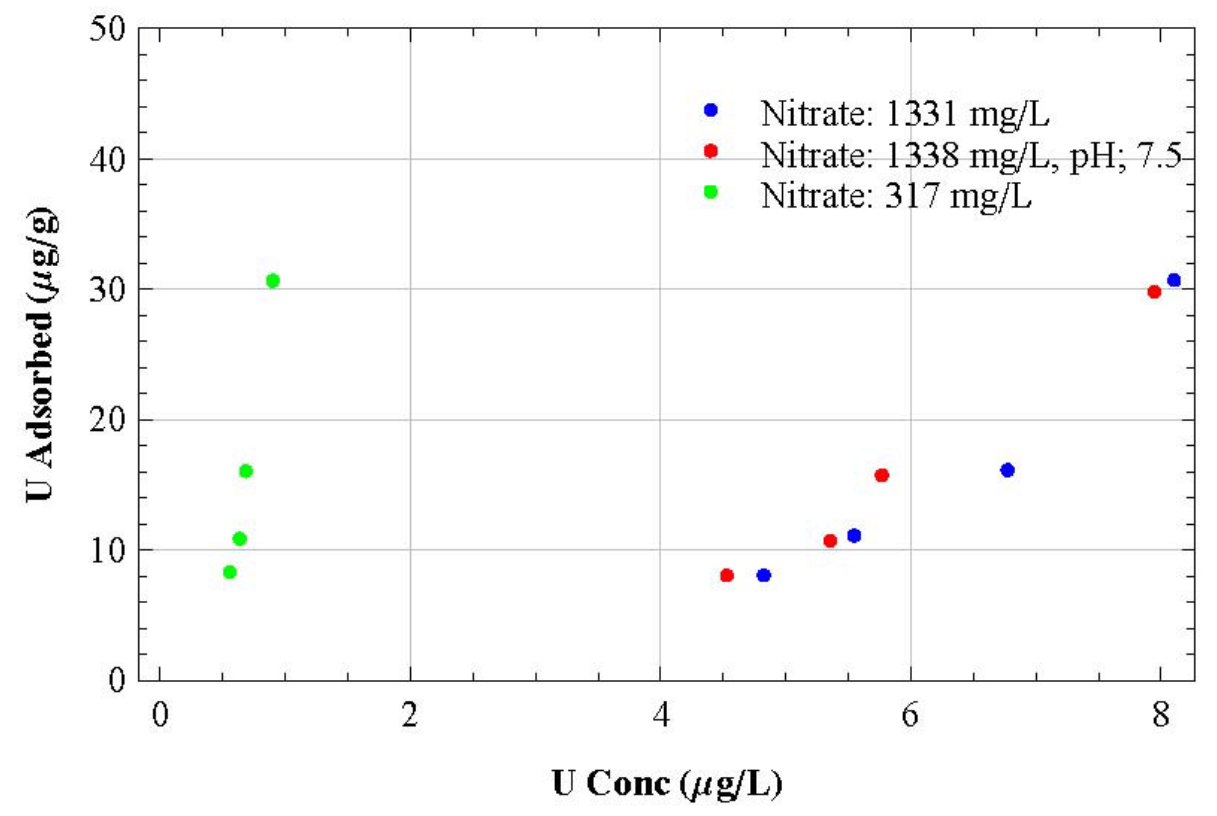

Figure 3.3. Langmuir Adsorption Isotherms for Uranium on Dowex 21K (Regenerated) Resin 


\section{Purofine PFA600-4740}

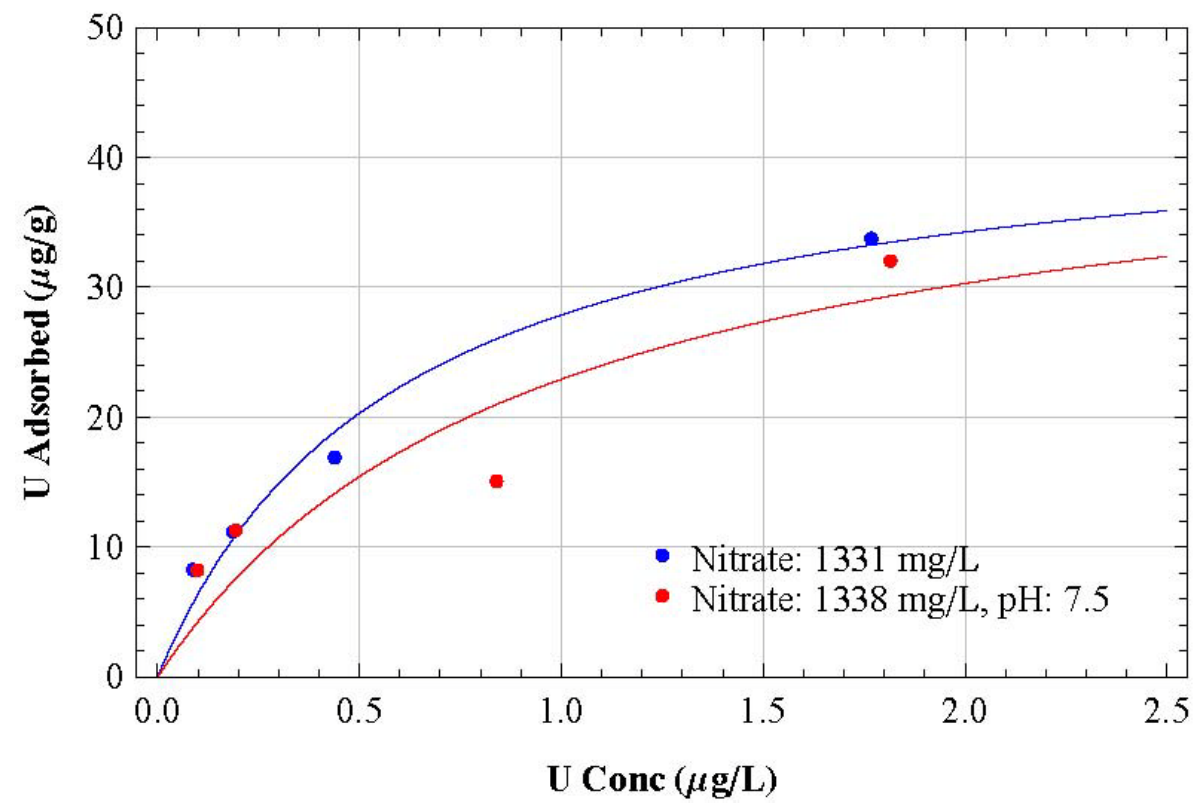

Figure 3.4. Langmuir Adsorption Isotherms for Uranium on Puroline PFA600-4740 Resin

\section{ResinTech SIR-1200}

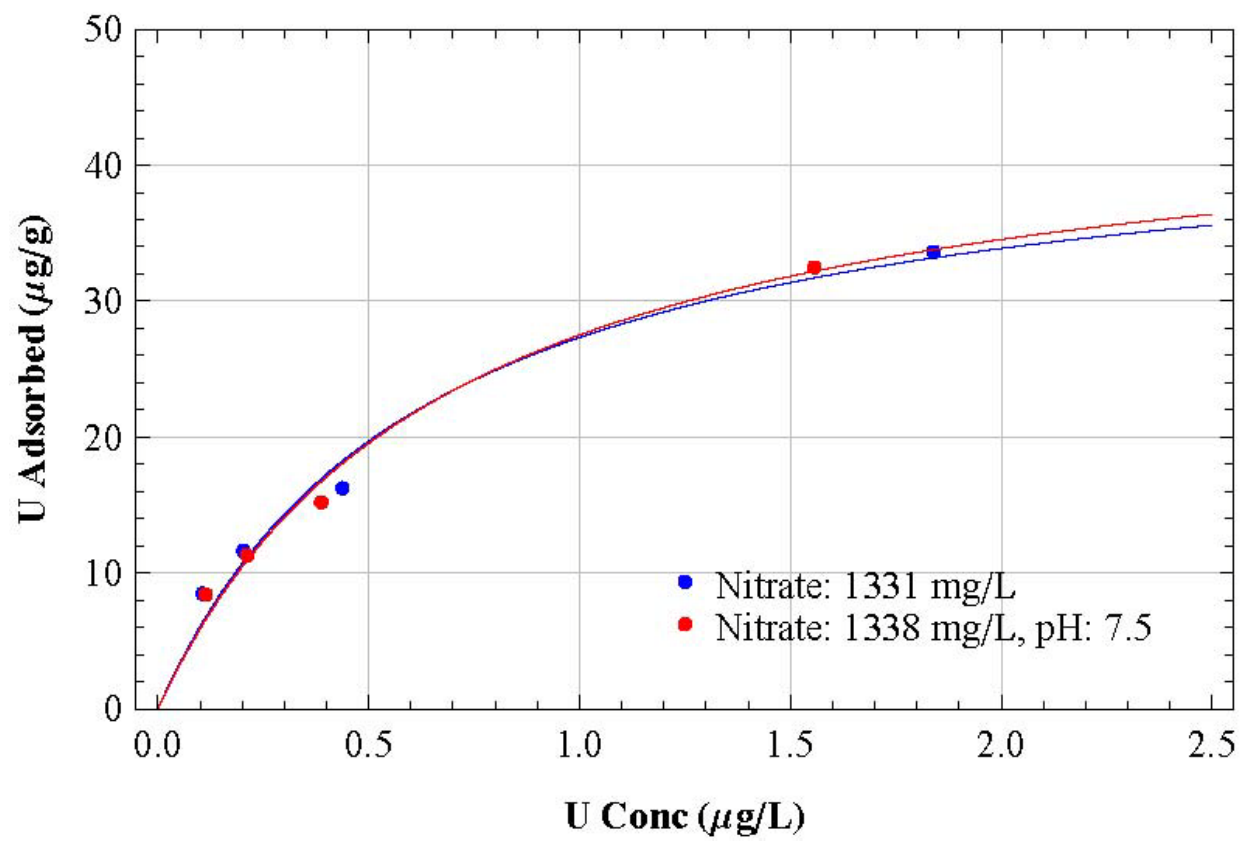

Figure 3.5. Langmuir Adsorption Isotherms for Uranium on ResinTech SIR-1200 Resin 
Nitrate 317 mg/L

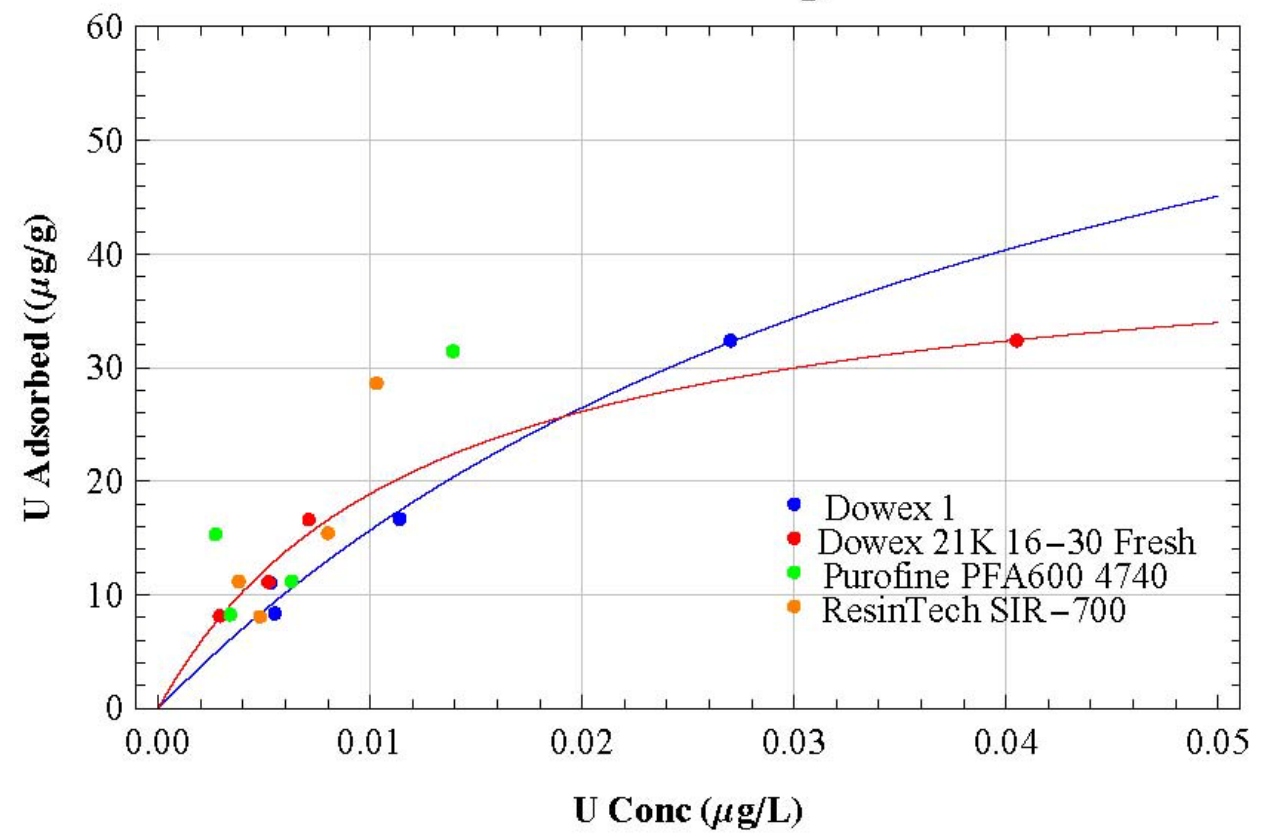

Figure 3.6. Uranium Adsorption Performance of Four of the Five IX-Resins Under Low Nitrate Concentration

Table 3.7. Langmuir Constants for Uranium Adsorption on Selected Ion-Exchange Resins

\begin{tabular}{|c|c|c|c|c|c|}
\hline $\operatorname{Resin}^{(a)}$ & $\begin{array}{c}\text { Nitrate Conc. (mg/L) } \\
\text { pH (SU) }\end{array}$ & $\begin{array}{c}\text { Langmuir } \\
\text { Constant } \\
\mathrm{K}_{\mathrm{L}}(\mathrm{l} / \mu \mathrm{g}) \\
\end{array}$ & $\begin{array}{c}\text { Predicted Ads } \\
\text { Maxima } \\
\text { M ( } \mu \mathrm{g} / \mathrm{g}) \\
\end{array}$ & $\mathrm{R}^{2}$ & $\begin{array}{l}\text { Predicted }^{(\mathrm{b})} \sim \mathrm{K}_{\mathrm{d}} \\
\text { (ml/g) at Ads } \\
\text { Maximum } \\
\end{array}$ \\
\hline Dowex 1 & 1331 & 1.24 & 43.40 & 0.9932 & 31,530 \\
\hline Dowex 1 & $1338,7.5$ & 1.09 & 45.11 & 0.9952 & 30,330 \\
\hline Dowex 1 & 317 & 22.68 & 84.87 & 0.9963 & 138,200 \\
\hline Dowex 21K 16-30 Fresh & 1331 & 0.80 & 57.63 & 0.9969 & 31,670 \\
\hline Dowex 21K 16-30 Fresh & $1338,7.5$ & 1.01 & 48.27 & 0.9952 & 30,940 \\
\hline Dowex 21K 16-30 Fresh & 317 & 80.36 & 42.42 & 0.9978 & 72,830 \\
\hline Dowex 21K 16-30 Regen. & 1331 & \multirow{3}{*}{\multicolumn{4}{|c|}{ (c) }} \\
\hline Dowex 21K 16-30 Regen. & $1338,7.5$ & & & & \\
\hline Dowex 21K 16-30 Regen. & 317 & & & & \\
\hline Purofine PFA600/4740 & 1331 & 1.69 & 44.41 & 0.9934 & 38,230 \\
\hline Purofine PFA600/4740 & $1338,7.5$ & 1.06 & 44.61 & 0.9504 & 29,480 \\
\hline Purofine PFA600/4740 & 317 & \multicolumn{4}{|c|}{ (c) } \\
\hline ResinTech SIR-1200 & 1331 & 1.59 & 44.57 & 0.9943 & 37,180 \\
\hline ResinTech SIR-1200 & $1338,7.5$ & 1.46 & 44.37 & 0.9960 & 35,360 \\
\hline ResinTech SIR-1200 & 317 & \multicolumn{4}{|c|}{ (c) } \\
\hline $\begin{array}{l}\text { (a) Styrene-DVB gel type, st } \\
\text { (b) Based on design U conce } \\
\text { (c) Adsorption data do not fit } \\
\mathrm{Q}=\mathrm{MK}_{\mathrm{L}} \mathrm{C} /\left(1+\mathrm{K}_{\mathrm{L}} \mathrm{C}\right), \mathrm{Q}: \mathrm{U}\end{array}$ & $\begin{array}{l}\text { ng base anion exchangers } \\
\text { ration of } 570 \mu \mathrm{g} / \mathrm{L} \text {. } \\
\text { angmuir isotherm. } \\
\text { sorbed/unit mass of Resin; }\end{array}$ & $=$ Equilibriu & Concentration. & & \\
\hline
\end{tabular}




\subsection{High Nitrate-Low pH Tests}

The results of testing with high nitrate $(1338 \mathrm{mg} / \mathrm{L})$ and lowered $\mathrm{pH}(7.5)$ adjusted source water are listed in Tables 3.2-3.6 and graphically displayed in Figures 3.1-3.6. The Langmuir parameters for the isotherms are tabulated in Table 3.7.

The data resulting from these set of tests did not differ significantly from the high-nitrate isotherm test (previous section). At all four resin-to-solution ratios, the observed uranium adsorption for Dowex 1, Dowex 21K 16-30 (fresh), Purofine PFA600/4740, and ResinTech SIR-1200 resin were similar (Tables 3.2, 3.3, 3.5 and 3.6). The $\mathrm{K}_{\mathrm{d}}$ for these four resins ranged from $\sim 15,000$ to $82,000 \mathrm{ml} / \mathrm{g}$. The adsorption maxima predicted from Langmuir equation fits to the data for Dowex 1, Dowex 21K 16-30 (fresh), Purofine PFA600/4740, and ResinTech SIR-1200 resins were 45.11, 48.27, 44.61, and $44.37 \mu \mathrm{g} / \mathrm{g}$, respectively (Table 3.7).

Also in these tests, the uranium-adsorption performance of regenerated Dowex 21K 16-30 resin was noticeably different than the performance of the fresh resin. First, depending on the resin-to-solution ratio, the final uranium concentrations in solutions contacting the regenerated resin were 5 to 30 times higher than the concentrations measured in solutions in contact with the fresh resin (Tables 3.3 and 3.4). Within the tested range of resin-to-solution ratios, the regenerated resin exhibited a relatively linear relationship between the mass of uranium adsorbed per unit mass of resin and the final uranium concentrations in the contact solution (Figure 3.3). The $\mathrm{K}_{\mathrm{d}}$ for this regenerated Dowex $21 \mathrm{~K} 16-30$ resin ranged from $\sim 1,800$ to $3,800 \mathrm{ml} / \mathrm{g}$ (Table 3.4), which are an order of magnitude lower than the $\mathrm{K}_{\mathrm{d}}$ values for the fresh resin.

\subsection{Low-Nitrate Tests}

The results of testing with as received source water (nitrate concentration $317 \mathrm{mg} / \mathrm{L}$ ) are listed in Tables 3.2-3.6 and graphically displayed in Figures 3.1-3.6. The Langmuir parameters for the isotherms are listed in Table 3.7.

The data resulting from these tests indicated that the uranium-adsorption performance of all resins was significantly better than the results obtained from the high-nitrate concentration source water. The $\mathrm{K}_{\mathrm{d}}$ for Dowex 1, Dowex 21K 16-30 (fresh), Purofine PFA600/4740, and ResinTech SIR-1200 resins ranged from $\sim 800,000$ to 5,600,000 ml/g. These $\mathrm{K}_{\mathrm{d}}$ values are one to two orders of magnitude higher than the values observed when the source water contained high-nitrate concentrations, indicating that enhanced concentrations of nitrate in the source water has an inimical effect on the uranium-adsorption performance of these resins. The adsorption maxima predicted from Langmuir equation fits to the data for Dowex 1 , and Dowex 21K 16-30 (fresh) resins were, 84.9 and $42.4 \mu \mathrm{g} / \mathrm{g}$, respectively (Table 3.7). The uraniumadsorption data for Purofine PFA600/4740 and ResinTech SIR-1200 could not be fit due to lack of data points in the non-linear parts of isotherms.

Compared to the fresh resin, the regenerated Dowex 21K 16-30 resin exhibited attenuated uraniumadsorption performance with $\mathrm{K}_{\mathrm{d}}$ values ranging from 15,000 to 34,000 mg/g. which are about an order of magnitude lower than the values calculated for the fresh resin. The adsorption isotherm for the regenerated Dowex 21K 16-30 resin was linear, so its adsorption maximum could not be ascertained (Figure 3.3). 


\subsection{Conclusions}

The uranium adsorption performance of five resins (Dowex 1, Dowex 21K 16-30 [fresh], Dowex 21K 16-30 [regenerated], Purofine PFA600/4740, and ResinTech SIR-1200) were tested using unspiked, nitrate-spiked, and nitrate-spiked/pH adjusted source water from well 299-W19-36. The results from these tests are as follows:

- The data from the high-nitrate (1331 mg/L) tests indicated that the uranium-adsorption performance of Dowex 1, Dowex 21K 16-30 (fresh), Purofine PFA600/4740, and ResinTech SIR-1200 all adsorbed uranium similarly well with $\mathrm{K}_{\mathrm{d}}$ values ranging from $\sim 15,000$ to 95,000 $\mathrm{ml} / \mathrm{g}$. The predicted uranium maxima for Dowex 1, Dowex 21K 16-30 (fresh), Purofine PFA600/4740, and ResinTech SIR-1200 using the Langmuir equation were 43.40, 57.3, 44.41 and $44.57 \mu \mathrm{g} / \mathrm{g}$, respectively, and would be considered suitable for use in the treatment system based on uranium adsorption characteristics.

- Lowering the $\mathrm{pH}$ of the high nitrate test conditions from 8.2 to 7.5 had no significant affect on uranium adsorption for the four tested resins. The $K_{d}$ values for the four resin ranged from $\sim 15,000$ to $80,000 \mathrm{ml} / \mathrm{g}$. The predicted uranium maxima for Dowex 1, Dowex 21K 16-30 (fresh), Purofine PFA600/4740, and ResinTech SIR-1200 using the Langmuir equation were 45.11, 48.27, 44.61, and $44.37 \mu \mathrm{g} / \mathrm{g}$, respectively.

- Higher nitrate concentrations greatly reduced uranium adsorption on all four resins. Tests conducted with unspiked (no amendments; nitrate at $337 \mathrm{mg} / \mathrm{L}$ and $\mathrm{pH}$ at 8.2) source water yielded $\mathrm{K}_{\mathrm{d}}$ values for Dowex 1, Dowex 21K 16-30 (fresh), Purofine PFA600/4740, and ResinTech SIR-1200 resins ranging from $\sim 800,000$ to 3,000,000 ml/g. These values are about two orders of magnitude higher than the $\mathrm{K}_{\mathrm{d}}$ values noted from tests conducted using amended source water. The adsorption maxima predicted from the Langmuir equation fits to the data for Dowex 1, and Dowex 21K 16-30 (fresh) resins were, 84.9 and $42.4 \mu \mathrm{g} / \mathrm{g}$, respectively. The uranium-adsorption data for Purofine PFA600/4740 and ResinTech SIR-1200 could not be fit due to lack of data points in the non-linear parts of the isotherms.

- Compared to the fresh resin, the regenerated Dowex 21K 16-30 resin exhibited significantly lower uranium-adsorption performance under all test conditions. The calculated $\mathrm{K}_{\mathrm{d}}$ values for the regenerated resin were typically an order of magnitude lower than the values calculated for the fresh resin. All isotherms for the regenerated resin did not conform to a Langmuir-type adsorption model.

- Additional testing using laboratory columns is recommended to better resolve differences between the adsorption abilities of the resins and to develop estimates of uranium loading on the resins. By determining the quantity of uranium that each resin can adsorb and the time required to reach various levels of loading, resin lifetime in the treatment system can be estimated. 


\subsection{References}

CHPRC. 2010. Test Plan for Uranium Ion-Exchange Resins. SGW-47531, Rev. 0. CH2MHill Plateau Remediation Contractor, Richland, Washington.

Comprehensive Environmental Response, Compensation, and Liability Act of 1980. 1980. Public Law 96-150, as amended, 42 USC 9601, et seq. Accessed January 10, 2011, at http://uscode.house.gov/download/pls/42C103.txt.

DOW. 1997. Application Information - DOWEX Ion Exchange Resins; Equilibrium Isotherm Testing for Liquid Phase Applications. The DOW Chemical Company, Midland, MI.

Ecology - Washington State Department of Ecology, U.S. Environmental Protection Agency, and U.S. Department of Energy. 1989. Hanford Federal Facility Agreement and Consent Order (Tri-Party Agreement). Document 89-10, as amended, Olympia, Washington. Accessed January 10, 2011, at http://www.hanford.gov/?page=81.

EPA - U.S. Environmental Protection Agency, Washington State Department of Ecology, and U.S. Department of Energy. 2008. Record of Decision Hanford 200 Area 200-ZP-1 Superfund Site, Benton County, Washington (transmitted via letter 09-AMCP-0003), Olympia, Washington. 
Appendix

Analytes and Analytical Methods 


\section{Appendix}

\section{Analytes and Analytical Methods}

The analytes and analytical methods for the testing are described below.

\section{A.1 Analyte List}

Influent water was analyzed for uranium, technetium-99, sulfate, nitrate, $\mathrm{pH}$, and alkalinity. Batch contact solutions were analyzed for uranium only.

\section{A.2 pH Analysis}

Approximately 3-ml aliquots of the unfiltered groundwater/test solution were used for $\mathrm{pH}$ measurement following Pacific Northwest National Laboratory’s (PNNL’s) procedure AGG-pH-001, "pH Measurements," which is similar to the U.S. Environmental Protection Agency’s (EPA's) SW-846, Test Methods for Evaluating Solid Waste: Physical/Chemical Methods, Third Edition; Final Update IV-B, Method 9040C (EPA 2004). Solution pH values were measured with a glass calomel pH electrode and a pH meter calibrated with appropriate buffers at 4, 7, and 10.

\section{A.3 Trace Metals Analysis}

Uranium and technetium-99 analyses of the groundwater/test solution were performed using an inductively coupled plasma-mass spectrometer (ICP-MS) following procedure PNNL-AGG-415, "Inductively Coupled Plasma Mass Spectrometry (ICP-MS) Analysis,", which is similar to SW-846, Method 6020A (EPA 1996). High-purity traceable single element standards traceable to the National Institute of Standards and technology (Ultra Scientific [(Kingston, RI] and Inorganic Ventures [Lakewood, New Jersey]) were used to generate calibration curves and to verify continuing calibration during the analytical run. A serial dilution was made of select samples to investigate and correct for matrix interferences. Typical instrument detection limits for the ICP-MS are in the range of parts per trillion.

\section{A.4 Alkalinity}

Alkalinity of the groundwater was measured by titrimetry in accordance with Standard Methods for the Examination of Water and Wastewater, Method 2320B (AWWA et al. 1998).

\footnotetext{
${ }^{1}$ Valenta MM. 2009. “pH Measurements.” AGG-pH-00 1, unpublished PNNL Technical Procedure, Pacific Northwest National Laboratory, Richland, Washington.

2 Clayton ET. 2008. “Inductively Coupled Plasma Mass Spectrophotometry (ICP-MS),” PNNL-AGG-415, unpublished PNNL Technical Procedure, Pacific Northwest National Laboratory, Richland, Washington.
} 


\section{A.5 Nitrate and Sulfate Analysis}

Nitrate and sulfate analyses of the groundwater/test solution was performed using PNNL's procedure AGG-IC-001, "Determinations by Ion Chromatography (IC),"1 which is similar to EPA SW-846, Method 9056A (EPA 2007). Nitrate was separated on a Dionex AS18 column with a sodium hydroxide gradient elution and measured using a conductivity detector. The only modification to the EPA ionchromatography method was the use of sodium hydroxide for gradient elution. High-purity calibration standards were used to generate calibration curves and to verify continuing calibration during the analytical run.

\section{A.6 References}

AWWA, APHA, and WEF. 1998. Standard Methods for the Examination of Water and Wastewater. 20th edition, American Water Well Association, Denver, Colorado; American Public Health Association, Washington, D.C.; and Water Environment Federation, Alexandria, Virginia.

U.S. Environmental Protection Agency (EPA). 1996. "Method 6020A, Inductively Coupled Plasma Mass Spectrometry,” Rev. 1. In Test Methods for Evaluating Solid Waste: Physical/Chemical Methods. EPA SW 846, EPA Office of Solid Waste and Emergency Response, Washington, D.C. Accessed June 1, 2010, at http://www.ppa.izov/epawaste/hazard/testrnethods/sw846/pdfs/6020a.pd.

U.S. Environmental Protection Agency (EPA). 2004. "Method 9040C, pH Electrometric Measurement," Rev. 3. In Test Methods for Evaluating Solid Waste: Physical/Chemical Methods. EPA SW 846, EPA Office of Solid Waste and Emergency Response, Washington, D.C. Accessed June 1, 2010, at httl2://www.epa.gov/epawaste/hazard/testrnethods/sw846/pdfs/9040c.pdf.

U.S. Environmental Protection Agency (EPA). 2007. "Method 9056A, Determination of Inorganic Anions by Ion Chromatography,” Rev. 1. In Test Methods for Evaluating Solid Waste: Physical/ Chemical Methods. EPA SW 846, EPA Office of Solid Waste and Emergency Response, Washington, D.C. Accessed January 11, 2011, at http://www.epa.gov/wastes/hazard/testmethods/sw846/pdfs/9056a.pdf.

\footnotetext{
${ }^{1}$ Lindberg MJ. 2004. “Determinations by Ion Chromatography (IC),” AGG-IC-001, unpublished PNNL Technical
} Procedure, Pacific Northwest National Laboratory, Richland, Washington. 


\section{Distribution}

No. of

Copies

ONSITE

DOE Richland Operations Office

J.G. Morse

A.C. Tortoso

CH2M Hill Plateau Remediation Company

B.F. Barrett

M.E. Byrnes

K. Hodgson

R.W. Oldham

J.G. Riddelle

B.L. Sasser

P. Sheely

S.A. Simmons

L.C. Swanson
Pacific Northwest National Laboratory

E. Cordova

PDF

E.C. Golovich

PDF

S.V. Mattigod

PDF

R.M. Smith

PDF

D.M. Wellman
PDF

PDF

PDF

PDF

PDF

PDF

PDF

PDF

PDF 



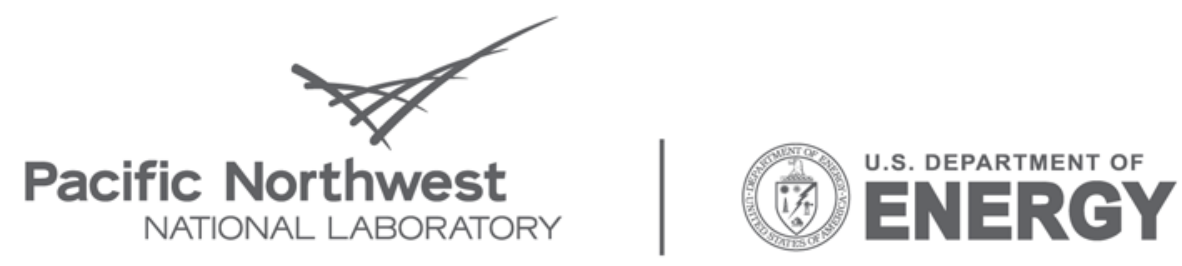

Proudly Operated by Battelle Since 1965

902 Battelle Boulevard

P.O. Box 999

Richland, WA 99352

1-888-375-PNNL (7665)

www.pnl.gov 